\title{
Internationalization Context of Arabia Higher Education
}

\author{
Salem Al-Agtash ${ }^{1,2} \&$ Labib Khadra $^{3}$ \\ ${ }^{1}$ Department of Computer Science and Engineering, Santa Clara University, Santa Clara, CA, USA \\ ${ }^{2}$ Department of Computer Engineering, German Jordanian University, Amman, Jordan (On leave) \\ ${ }^{3}$ Department of Electrical Engineering, Al-Hussein Technical University, Amman, Jordan \\ Correspondence: Salem Al-Agtash, Santa Clara University, 500 El Camino Real, Santa Clara, CA 95053, USA. E-mail: \\ alagtash@gmail.com
}

Received: March 13, 2019

Accepted: April 13, 2019

Online Published: April 17, 2019

doi:10.5430/ijhe.v8n2p68

URL: https://doi.org/10.5430/ijhe.v8n2p68

\begin{abstract}
Internationalization in Arabia higher education space is expanding rapidly. It has taken different shapes with no systematic approach to evaluate its success and impact. By analysing patterns of mobility; trends; and forms of academic cooperation in Arabia, a framework for internationalization is introduced. The purpose is to guide efforts towards a strengthened position of higher education in the international dimension. Internationalization promotes the idea of making the university a dynamic cross-boarder educational environment. The higher education space in Arabia is analysed mainly in the internationalization perspective. The German Jordanian University is presented as an illustrative example. The objective is to draw on its experience as a benchmark for devising a workable scenario for implementing internationalization as an important dimension of higher education. The results show the importance of the derived benefits of study abroad, program cooperation, partnership, internship, and research collaboration as essential ingredients of internationalization in higher education systems.
\end{abstract}

Keywords: Arabia higher education, internationalization context, German Jordanian University

\section{Introduction}

Internationalization has become a worldwide trend in higher education. It is considered as a key driver for fostering mobility of students and staff; introducing offshore distance teaching and learning; motivating cross-border education; and increasing academic collaboration. Internationalization is also seen as a vehicle to build a system of international standards and to uphold quality of education for an adequate preparation of qualifications to meet globalization requirements of labour markets, economies, and societies (Marjorie, 2000; Qiang, 2003). Its direct benefits include knowledge acquisition, curricula enhancement, economic advantage, and workforce development. As a result of this growing trend, new challenges have become apparent. Lack of supportive educational policy, less efficient teaching and learning pedagogy, limitation of digital education delivery, and mismatch between academic quality and recognition are among the prevailing challenges.

\subsection{General Perspective of Internationalization}

Internationalization on a general perspective has been given much attention in the literature of higher education. Arabkheradmand et al. (2015) see internationalization of higher education a limitation towards achieving the desired growth of educational organizations, which in turn brings about the growth of individuals and the progress of human societies. Altbach and Knight (2007) present motivations and realities of internationalization in higher education, with efforts at the international level to leverage internationalization benefits. It was concluded internationalization remains a central force in higher education providing substantial access in some countries and representing a niche market in others. Knight (2004) presents internationalization as a process that takes different forms of integration of international and intercultural perspectives without specifying rationales, benefits, outcomes, activities, and actors as they vary across nations and institutions. It was also defined as a response of a country to the impact of globalization (Qiang, 2003) or as an organizational adaptation through its process of planning and implementation (Bartell, 2003). Internationalization is becoming an inevitable process even if it is not supported by national governments, (Knight, 2003; Van der Wende, 2007).

Globalization and internationalization trends, issues and challenges vary and have been thoroughly addressed in a local and regional context using a wide range of methods and approaches (De Wit, 2011). Siaya (2003) addresses 
campus-based internationalization initiatives with focuses on study abroad, international studies, foreign language, and student sponsorship. Marginson (2006) explores the dynamics of competition in higher education both national and global. Emphasis has been on the importance of the development of national higher education capacity to modify global asymmetries and unidirectional transformations. Rizvi and Lingard (2009) present educational policy in a globalized manner with emphasis on the development of theoretical and methodological approaches in the rethinking of internationalization at home and abroad. Maringe and Foskett (2010) provides a broad overview of globalization and internationalization with outlines on the challenges for universities operating in the global environment, namely: dominance of western models, prevalence of limited views of internationalization, incoherence in university structures, and lack of strategies and leadership insights.

\subsection{Trends of Internationalization in the Arab Region}

The above references serve as the general internationalization background for the analysis undertaken for the Arab higher education systems in the twenty-two member countries of the League of Arab States. The internationalization perspective is considered in the international and intercultural dimension of teaching, research and community service (Knight, J. 2006). Internationalization in education in the Arab region is a growing phenomenon. It has been recognized as a significant source of development in light of the dramatic expansion and declining status of the Arab higher education sector. The United Nations Educational, Scientific and Cultural Organization (UNESCO, 2009) has reported on Arab higher education as it continues to fail to meet the needs of students, employers, and the society at large. It was noted that the majority of Arab higher education institutions lack key human and physical resources for success. The institutions are overcrowded and suffer from poor quality education delivery. This has mainly resulted in graduates with qualifications that do not match the labour market requirements. Jaramillo (2011) indicates Arab higher education institutions are much less engaged internationally compared to institutions in more developed higher education sectors.

An opportunity for Arab higher education institutions, therefore, is to align with the global educational systems and trends to develop academic values and standards through internationalization. This would provide access to internationally recognized resources, legitimacy, and credible accreditation to some extent. Accreditation, however, does not address the quality of internationalization of an institution, nor does internationalization present a solution to many of the prevailing problems of higher education systems.

\subsection{Motivation and Framework}

Unfortunately, no research yet reports on the internationalization efforts and policies from the perspective of Arab higher education. There is a lack of informed analysis about key issues, trend, and prognoses for the future. In fact, much of the available research and studies focus on Arab higher education reforms, policies, and governance in a general framework (Mazawi, 2006). The studies are mainly motivated by international and regional organizations such as the UNESCO. This paper is intended as a contribution to report on the profile and perspectives of internationalization in the Arab higher education systems. Varieties of implementations exist but there is no clear policy directions on the potential elements of effective internationalization that can guide efforts towards a strengthened position of Arab higher education in the international dimension.

On the basis of the analysis of mobility patterns, internationalization trends, and forms of academic cooperation, a framework is introduced. The framework presents internationalization as an approach to enhance academic values and quality, foster cultural understanding, promote mobility, and create partnerships. The German Jordanian University is presented as an illustrative example to build a case for how internationalization though limited in a bi-national university structure might be leveraged by other institutions, based on a key set of priorities, and paying attention to the opportunities and imperatives, obstacles and challenges present in the region. Results of the example reinforce common ideas about the ingredients for success as measured using mobility and partnership metrics in a case study of an approach to internationalization.

\subsection{Research Methodology}

The methodology of research involves analysis of trends and collection of different sources of data on internationalization of higher education. The analysis focuses on conceptualizing the status of Arab higher education systems in the given variations of the region; identifying existing mobility schemes and internationalization trends; and presenting a rather successful example of international cooperation. Success is measured by metrics of the main internationalization elements.

The methodology is composed of three steps. In step 1, data from different sources, including reports and presentations from the Association of Arab Universities, UNESCO, League of Arab States, University websites, conferences, and 
educational forums is presented. The data elements and indicators are analysed to conceptualize the status of Arab higher education with respect to student population, faculty, academic programs, mobility schemes, qualifications mismatch, research spending, and collaboration. On the basis of these analyses, internationalization elements are identified. Finally, the factual data of the German Jordanian University are used as metric values of internationalization. These values are obtained through a combination of archival sources and observations.

In step 2, a mapping process is used to present a descriptive illustration of elements, facts, and trends. The illustrations are used to explain the status of Arab higher education and its growing internationalization phenomenon. On the basis of these explanations, an internationalization framework is developed.

In step 3: The German Jordanian University is analysed and presented as a working example of internationalization using the constructs of the framework. The outcome was a series of evaluation metrics showing different success elements. The metrics demonstrate quantitative measures with respect to internationalization, mobility, knowledge transfer, program implementation, internal performance, and gains at the macro and micro economic levels.

\section{Higher Education in Arabia}

The Regional Bureau for Arab States in United Nations Development Program (UNDP, 2009), reported an estimate of $60 \%$ of the population in the Arab countries is under the age of 25 years. This large young population places limits on education capacity and creates new economic challenges. Unless effective policies are matched with accelerated educational reforms and with up-scaling innovation, the Arab countries are unlikely to capture the vital energy of the youth and meet their ambitions for more opportunities and inspiration. We present the current status of the Arab higher education from different angles, mainly: government spending, student enrolment, internationalization, ongoing efforts for improvement, and a need for a common space of higher education. Given the enormous cultural, economic, and education disparities, significant regional variations exist across the Arab higher education sector. For example, the political and cultural dimensions are not uniform and so the resultant constraints and affordances would impact greatly the quality dimensions and the nature of the higher education structures.

\subsection{Government Spending}

Public university structures are dominant in the Arab region. They constitute over $65 \%$ of the total number of Universities. Available reports and keynote speeches related to higher education at the League of Arab States (www.lasportal.org) and Association of Arab Universities (www.aaru.edu.jo) have shown that government spending on higher education is limited. The total Arab regional spending is about 5\% of the global spending on higher education. In contrast, the spending of industrialized countries is about $60 \%$ of the global spending (Schwalje, 2010). As a matter of fact, the average expenditure per student per year does not exceed $5 \%$ of the amount spent per student per year in the industrialized countries. For research and development, the average spending is much less than $0.5 \%$ of the total GDP, compared to 2-3\% of the total GDP in the industrialized countries (ALECSO, 2010). Though the big picture of Arab higher education is not promising, there is a growing move towards developing better education systems with more technologies being integrated to keep in pace with recent advancements and trends.

\subsection{Student Enrollment}

Student enrollment in the Arab countries has reached 20 million in about 1000 Arab institutions mainly universities, community colleges, and teacher-training institutes (UNESCO, 2009; ALECSO, 2010). About 9 million of the students are enrolled in universities. Of them $10 \%$ are enrolled in postgraduate studies (8\% master, $2 \%$ doctorate). This low enrolment in doctorate programs dramatically impacts advancement of research and development in the Arab region.

It has also been reported (UNESCO, 2009; ALECSO, 2010) that $80 \%$ of the undergraduate students are enrolled in humanities, and only $20 \%$ are enrolled in scientific programs. This creates a disproportionate number of graduates mainly in humanities and very little in science and technology. Meanwhile, the high number of students per faculty is considerably high, reaching on average 71:1 in business schools and about 15:1 in science and technology. The ratio in the industrialized countries is about 5:1, presenting a huge difference.

The continuing rise in the number of students has motivated the private sector to invest in higher education, leading to the emergence of new types of education such as open and virtual universities, offshore international campuses, and bi-national universities. These opportunities will open up room for increased internationalization, hence access to qualified resources and credible accreditation to some degree. 


\subsection{Mobility}

The mobility dimension has not been given much attention in the Arab higher education systems. It has been characterized as an outgoing mobility for studying abroad for a full degree that is mainly supported through private and public funding. The outgoing mobility for short-term study abroad is limited and mainly supported by funding programs such as Erasmus Mundus. Incoming mobility in the Arab region is reported on student interests for studying language, culture, religion, and history, mainly from Eastern Asia, North America, and Africa regions.

Available statistics have shown that on average only $2.9 \%$ of the students of Arab universities come from in-between other Arab countries and $0.8 \%$ from non-Arab countries. This gives a total inward mobility (both Arab and international students studying for full-degree programs in Arab Universities) rate of 3.7\% (UNESCO, 2009). Assuming a constant average rate of inward mobility during the past decade, this percentage represents $2.5 \%$ of the global student mobility, (Varghese, 2008). In contrast, the inward mobility in North America and Western Europe is estimated at $65 \%$ of the global student mobility. Obviously, the recent issues and instabilities in the region have dramatically affected the inward mobility. The inward mobility in Arab universities is still considered very low. On the contrary, outgoing students from the Arab countries is relatively high. According to Varghese (2008), the outward mobility from the Arab region is estimated at 7.2\% of the global mobility. UNESCO (2009) shows the outward mobility at the postgraduate level estimated at 53\%, mainly in doctorate programs, of which $80 \%$ is in North America and Western Europe, Varghese (2008). Thus, the flow is largely one-directional, resulting in a foreign cultural pattern in the Arab regional context.

\subsection{Expansion and Innovation Efforts}

In general, the Arab higher education is still under development. Challenges and issues are tremendous, which include limitations on funding, localized quality standards, lack of policy directions, and inadequate educational resources. Arab governments have made several expansions and innovation efforts towards improvement. The efforts focus on forming partnerships; establishing effective support and quality assurance systems; and increasing research spending.

On the partnership dimension, it has been reported that a new trend of educational structures has emerged, mainly based on cooperation agreements with foreign universities. Rena (2010) have pointed out that United Arab Emirates, Qatar, Saudi Arabia, and Egypt stand out as examples of countries that have boldly promoted internationalization by recruiting prestigious foreign universities to establish local campuses, with the goal of expanding access for the local student population and serving as higher education "hubs" for their regions.

In the United Arab Emirates, for instance, the Dubai international academic city - a free education zone - was established to host several western universities from the UK, the USA, Australia, India and many other countries (MEI, 2010). A similar setup has been formed at Sharjah - Sharjah University City. The objective has been to develop the region's talent pool and establish the UAE as a knowledge-based economical hub.

Qatar Education has incorporated a system of education with various institutes and branches of leading universities, including Virginia Commonwealth University, Texas A\&M University at Qatar, Weill Cornell Medical College in Qatar, Georgetown University and Carnegie Mellon University. Participating institutions receive substantial subsidies and incentives to position Doha as a source of highly trained elites in several professions (MEI, 2010).

In Saudi Arabia, King Abdullah University of Science and Technology emerged as an innovative example of partnership with world leading universities to develop highly recognized science and technology degree programs. In Egypt, the American University in Cairo, the German University, and the British University are examples of internationalized university campuses. In Jordan, an agreement was signed with the Bundesministerium für Bildung und Forschung - BMBF (The German Federal Ministry of Education and Research) to establish the German Jordanian University, with an objective to enhance technology education and mobility of students. In Tunisia and Bahrain, partnership with foreign institutions has also been formed to develop short-term programs and faculties with vocational emphasis.

On support systems, ICT infrastructures and Quality Systems are key developments in the Arab higher education systems. ICT networks, tools, applications, content repositories play important roles in the academic transformation. The Internet has truly revolutionized pedagogies of teaching and learning as well as access to knowledge resources. It represents a prominent virtual space for academic collaboration, joint research, and access to eJournals, eSciences, Open curricula, and Computing facilities that are not available locally. Furthermore, ICT presents a potential resource in the development of national information systems, national research and education networks, university portals, digital libraries, research databases, and e-learning pedagogies. It also contributed to the development of open and distance education allowing for new types of educational repositories, curricula resources, and pedagogical tools. Yet, 
realizing the full potential of ICT entails enormous costs and difficulties to maintain up-to-date hardware and software as well as their continual technical support and upgrades. Arab countries like Iraq, Libya, Yemen, Djibouti, Comoros, and Somalia remain relatively underserved by ICT tools and resources.

In the support of quality systems, fifteen Arab countries (Lamine, 2010) have either establish national commissions for quality assurance and accreditation or motivated the development of quality assurance programs and capacity building projects to uplift the quality of their national higher education systems. It has been noted that quality focus remains oriented toward the accreditation of private university without solid tangible achievements and legislative implementations. Quality assurance will continue to be a high priority in the light of the globalization of higher education and increasing student enrolment in private institutions.

On research spending, efforts are limited to policy directions at the regional and national levels. Badran (2005) presents a deteriorating status of research and development in the Arab region, much attributed to the lack of funding, political interest, and supporting environments. Research spending is estimated at best one-tenth of that spent in the industrialized countries. The private sector can play an important role with collaboration venues created for transfer of foreign knowledge, technology, and expertise. Governments in United Arab Emirates, Jordan, Saudi Arabia, and Oman, for example, launched research initiatives, including scientific research commissions, centers of excellence, science councils, business and technology parks, and incubators (Lamine, 2010). These initiatives may be consolidated at the regional level to stimulate cooperative research that addresses common pressing problems in the region.

\subsection{Common Space of Higher Education}

Regions such as Europe and Latin America have developed structured common spaces for higher education. These spaces served as instruments to align education systems, facilitate academic cooperation, and produce compatible skilled labours for the regional and global job markets. In the Arab region, there is an urgent need for an Arab higher education space to promote regional harmonization between higher education institutions. What exists today is the UNESCO Convention on the Recognition of Qualifications, which was signed by 14 Arab countries in 1978. The Convention is not adequate when it comes to issues related to compatibility of educational delivery systems as well as to mobility and employability of millions of students.

Today, higher education has become a sector of regional perspective to support social and economic development rather than being a sector restricted by national boundaries. With a common educational space, there is a potential opportunity to help in facilitating mobility, recognition, credit transfer, and quality as well as enhancing harmonization between Arab higher education systems. More importantly, students would have more choices in cost and quality and faculty would establish closer collaboration in research.

The specific challenges facing the region on this issue, however, are enormous. These include curricula incomparability, diversity in program structures and qualifications (year basis versus credit hours), barrier to language and communication (French versus English as medium of instructions mainly in science programs), and lack of policy directions and awareness. A state of readiness is needed at the macro level, so that policy makers agree on the main principles of a common space. With vast differences in the structures of Arab higher education systems, creating such a space remains a difficult task. It is very likely that a preliminary common space may be motivated on the basis of multi-national qualifications, inter-university semester study abroad, and regional research collaboration driven by funding and policy development mechanisms.

\subsection{Opportunities}

Internationalization in Arabia has been inspired by offering foreign students short-term courses and often full degrees in Islamic and Arabic Language Studies. In contrast, internationalization in Europe has been driven by governments providing funding to stimulate mobility of students and faculty. In North America, universities have been attractive to many international students and scholars. Overall, mobility of students and faculty is seen to contribute to the development of international cooperation and networking and represents a source of change in society integration.

Internationalization brings potential benefits and valuable and diverse academic and cultural experiences. It helps to bring institutions closer, through which, quality of education can be improved, innovation can be fostered, best practices in learning and teaching can be disseminated, and employability of students in the international job market can be enhanced. It is also seen as a strategic choice for many Arab institutions, leading them to use existing western mobility networks intensively. Examples of networks in Europe include Erasmus-Mundus, Tempus, and framework programs. In the USA, mobility networks include the CIEE exchange program, International Student Exchange Programs, Academic Year in America, the Fulbright international educational exchange program, and the Hubert Humphrey fellowship program. However, these networks are limited, highly competitive, and available to global 
communities. Arab educational policies still lack internationalization and globalization component, and so very few mobility networks are available at the Arab regional level. The Safar Youth Mobility Fund is an example. Other forms of mobility are based on bilateral exchange agreements funded by ministries of foreign affairs through scholarship programs for foreign students.

\section{Internationalization Framework}

The measurement of success in internationalization is influenced by the parameters used in the core processes of a university, i.e., teaching, research, and community engagement (Coelen, 2009). Internationalization of teaching is vital when it is a strategic priority of a university to recruit international students, motivate mobility, and prepare graduates for the global job market. This poses a great challenge, as it requires a university to make teaching of international relevance as well as to prepare students as global citizens equipped with the skills that are intercultural and multi-lingual. From a research perspective, internationalization is achieved through access to global research funding, involvement of faculty in research projects and communities tackling issues and problems of a global significance, and publication of results in globally indexed journals and conference proceedings. Finally, community engagement is another core process that may be internationalized. This can be achieved through peering and twining of communities across different countries as well as involving international organizations and businesses in community services in regard to continuing education and professional development.

The international dimension in these core processes differs considerably and could lead to different interpretations of internationalization compliance. Therefore, a framework is necessary to identify the core elements of internationalization, which can serve as spontaneity benchmarks. Figure 1 gives the proposed framework characterized in three main layers. The top layer represents the institutional internationalization strategy implemented through leadership policy, developing institutional partnerships, and forming an active international office. The middle layer gives measurable elements for each core of university processes, namely: Teaching, Research, and Community engagement. Finally, the bottom layer defines expected performance, outcomes and long-term impact characterized through employability, ranking, and national economic standing.

\begin{tabular}{|c|c|c|}
\hline \multicolumn{3}{|c|}{ Institutional policy embedding internationalization as a strategic priority } \\
\hline - Leadership policy & - International office & - Institutional partnership \\
\hline $\begin{array}{c}\text { Teaching } \\
\text { International relevance } \\
\text { Intercultural multilingual skills }\end{array}$ & $\begin{array}{c}\text { Research } \\
\text { Research of global significance } \\
\text { Publication of international value }\end{array}$ & $\begin{array}{l}\text { Community } \\
\text { International engagement } \\
\text { Professional development }\end{array}$ \\
\hline $\begin{array}{l}\quad \text { Measurable elements } \\
\text { - Curricula structure } \\
\text { - Faculty with international } \\
\text { experience } \\
\text { - Student mix } \\
\text { - Study abroad and mobility } \\
\text { - Cultural and multi-lingual } \\
\text { integration } \\
\text { - Flying faculty co-teaching }\end{array}$ & $\begin{array}{l}\quad \text { Measurable elements } \\
\text { - Joint research projects with } \\
\text { international peers } \\
\text { - External research funding } \\
\text { - Faculty with international/ } \\
\text { industrial experience } \\
\text { - Research visits and staff exchange } \\
\text { - SI indexed publications }\end{array}$ & $\begin{array}{l}\text { Measurable elements } \\
\text { - Community development } \\
\text { projects } \\
\text { - Continuing education } \\
\text { programs } \\
\text { - Professional qualification } \\
\text { programs } \\
\text { - International twining activities }\end{array}$ \\
\hline \multicolumn{3}{|c|}{ Performance, outcomes, and long-term impact } \\
\hline - Employability of graduates & - Institutional ranking & - National standing \\
\hline
\end{tabular}

Figure 1. Internationalization framework

The framework is set instrumental in the characterization of internationalization efforts. The metrics are both numeric and descriptive and can depict the value of internationalization in a continuous time frame. We provide the German 
Jordanian University as an illustrative example for demonstration. It should be noted that institutions may have different set of customized elements and evaluation metrics depending on their own targets. In the next subsections, we give details on the core elements of the framework and their characterization and related metrics.

\subsection{Institutional}

At the institutional level, internationalization is taken as a policy envisioned and implemented by the leadership of a university. It is reflected in the strategy implementation and institutionalized through cooperation agreements and international office setup. Brandenburg and Federkeil (2007) propose an internationalization process and methodology that include identification of goals, development of strategy, and compilation of an implementation plan, measures, and a quality system.

A key indicator of how serious internationalization is taken at the institution is the activation of partnership/ cooperation agreements with peer universities abroad. Partnership takes different forms and fosters collaboration for carrying out joint research projects and developing cooperative degree programs. From a joint research perspective, faculty from different universities work together through different funding schemes on research problems that are of global significance. From a program perspective, cooperating universities offer degrees in the form of a traditional or an online/ blended program structure. One of the objectives is to make available globalized degree programs with components that foster cross-cultural understanding and at the same time focus on skills for the global job market.

Some universities cooperate to offer sub-degree, degree, or post-graduate programs designed in a twinning structure, franchised, or joint/ double degree award. In a franchising agreement, for instance, a university is authorized by a foreign university to offer courses or programs in its own country with the qualifications of the foreign university. In this case, arrangements for teaching, assessment, degree, or credit awarding are made in compliance with the national regulations of the host university. In a twinning structure, students take courses for credits at a foreign university. Unless the arrangements are made for joint or double degree, students obtain their degree from their home institution. In a joint or double degree structure, students obtain their degrees from both the host and the foreign institutions.

In measuring the institutional core element of internationalization, several metrics can be used. As shown in table 1, we propose metrics that are related to institutional policy, cooperation agreements and structure, international office setup, and cultural integration value.

Table 1. Metrics of institutional core element of internationalization

\begin{tabular}{ll}
\hline No. Description \\
\hline 1. & $\begin{array}{l}\text { Evaluate institutional policy statement that defines vision, mission, and targets and related } \\
\text { strategic directions and implementations }\end{array}$ \\
2. Evaluate the number, structure, and scope of the cooperation/ partnership agreements with peer \\
institutions abroad \\
3. Evaluate the organization structure, operation procedures, and effectiveness of a national office \\
setup in the coordination of all relevant internationalization activities \\
4. Evaluate the cultural integration value in the institution core processes including multi-lingual \\
skills, awareness, and tolerance
\end{tabular}

\subsection{Teaching}

The internationalization of teaching takes different forms, including curricula design, international student enrolment, study/ internship abroad, cultural dimension, and foreign faculty employment. In these forms, actors are students, faculty, scholars, experts, and professionals. In curricula design, cooperating universities work together in developing curricula of international relevance with standards that are compliant to both national and international qualification frameworks. Credits, courses, syllabi, learning outcomes, pedagogical structures are jointly defined. It is also important to embed in the learning process language and cultural competencies, which can be implemented in variety of methods. With compatible curricula and cultural/ multi-lingual components, universities can easily recruit international students.

In study abroad, students tend to spend a semester or a year abroad as part of their degree or enrol in a joint/ double degree program at a university in a foreign country. This currently represents the largest form of internationalization and is growing. However, many concerns and issues exist, including financing, language barriers, and credit transfer. Internship or practicum in a foreign country enhances mobility and strengthens practical and inter-cultural experiences. In some technical degree programs, practicum is a requirement for graduation, and often is required in a foreign 
country, which adds another intercultural dimension. In some cases, the practicum contributes to enhance foreign employment of graduates, which can impact knowledge transfer and but can lead to a reverse impact with respect to "brain drain" phenomenon.

Institutions contribute to internationalization of teaching in another dimension by opening branch universities in a foreign country with a tendency in some cases for merger and acquisition. In this case, a university establishes its own campus in a foreign country to deliver a course or program to students in their home country. Some foreign universities and private companies tend to establish a stand-alone virtual and corporate university or independent institution. Oracle University is an example of an independent virtual university, which offers vendor-specific certification and courses. Talal Abu-Ghazaleh University is a virtual university based on academic partnerships with world leading universities. It offers courses for credit and full degree programs to students in different countries through online education. Virtual universities and online education are relatively small but are seen to have great potential in the future. Quality of instructions and delivery will remain a major concern. Substantial cooperation brings value through foreign faculty teaching and co-teaching assignments as well as short-term visits and long-term appointment.

The metrics to measure teaching as a core element of internationalization are related to curricula structure, study abroad, internship abroad, international students, staff exchanges, internship abroad, cultural and multi-lingual practices, and foreign faculty involvement and employment. Table 2 gives details of the metrics of significance as far as teaching is concerned.

Table 2. Metrics of teaching as a core element of internationalization

\begin{tabular}{|c|c|}
\hline No. & Description \\
\hline 5. & $\begin{array}{l}\text { Evaluate the process through which curricula are developed with focus on compliance to national } \\
\text { and international qualification framework requirements; syllabi covering learning outcomes of } \\
\text { international significance, pedagogical approach emphasizing on language and multi-cultural } \\
\text { skills }\end{array}$ \\
\hline 6. & $\begin{array}{l}\text { Evaluate the process through which international students are recruited as well as the } \\
\text { quantification of student mix and ratio }\end{array}$ \\
\hline 7. & $\begin{array}{l}\text { Evaluate the organization structure, operation procedures, and effectiveness of the international } \\
\text { office in its coordination of all relevant internationalization activities across the institutions }\end{array}$ \\
\hline 8. & $\begin{array}{l}\text { Evaluate the cultural integration value in the institution core processes including multi-lingual } \\
\text { skills, awareness, and tolerance as well as the extra-curricula activities that nurture these skills }\end{array}$ \\
\hline 9. & $\begin{array}{l}\text { Evaluate the proportion of faculty with international experience as well as foreign faculty } \\
\text { engagement in teaching }\end{array}$ \\
\hline 10. & $\begin{array}{l}\text { Evaluate activities profile of faculty engaged in short-term teaching visits as well as participation } \\
\text { of flying faculty co-teaching }\end{array}$ \\
\hline
\end{tabular}

\subsection{Research}

Joint projects that are on international merits, field and research work, sabbaticals abroad, and short-term visits are important factors that contribute to boosting the international dimension of research. Scholars often obtain grants to spend a short-term period at foreign institutions to pursue research in specific academic disciplines. Grants are awarded for specific research projects, guest professorships, or internship activities in industry.

Additional research activities can involve funding and participation in research communities working on problems and issues that are of a global nature. It is also important to identify and recruit faculty with international and industrial experience to contribute to the research profile and developing joint graduate programs at the doctoral level. Research activities will surely contribute to valuable publications that are Thompson indexed.

Several research programs of this sort exist worldwide, including the German DAAD, the US Fulbright and NSF, and the European exchange and framework programs. Research programs at Arab universities tend to involve guest professorship for sabbaticals and are limited to collaboration with institutions in Europe, the USA, and other developed countries. Faculty, staff, and scholars collaborate with their peers in a foreign institution mainly on academic projects supported by special mobility programs such as EU Erasmus, Marie Curie, and the German Humboldt. The academic projects can involve joint research, capacity building, and other educational projects. 
The metrics we use for the research dimension of internationalization are given in Table 3, mainly focusing on research projects with international merits, external funding, faculty with international experience, research visits, and publications.

Table 3. Metrics of research element in internationalization

\begin{tabular}{l} 
No. Description \\
\hline 11. Evaluate faculty research profile and merits of projects and involvement in research problems \\
with international cooperating partners \\
12. Evaluate the merits and number of internationally funded research projects and active \\
involvement of faculty \\
13. Evaluate the process through which a university recruits faculty with strong international research \\
profile and experience \\
14. Evaluate the support of university and involvement of faculty in research visits and staff \\
exchange activities \\
15. Evaluate the publication profile and the number of SI indexed publications per researcher and \\
number of international citations \\
16. Evaluate study programs at both undergraduate and graduate levels that support research \\
activities and student involvements in research-oriented projects and theses
\end{tabular}

\subsection{Community Engagement}

Community engagement is another core process that can be internationalized. This can be achieved through supporting community development in different perspectives. These include projects that target communal concerns, continuing education that addresses professional development, and support services that promote access to knowledge resources.

The metrics we use for the community engagement dimension of internationalization are given in Table 3, mainly focusing on development projects, continuing education, partnerships for professional qualifications, communal activities that support cultural integration and twining activities worldwide.

Table 4. Metrics of community element in internationalization

\begin{tabular}{|c|c|}
\hline No. & Description \\
\hline 17. & $\begin{array}{l}\text { Evaluate university active engagement in community development projects which address the } \\
\text { society at large }\end{array}$ \\
\hline 18. & $\begin{array}{l}\text { Evaluate whether or not a center of continuing education exists and that it offers on regular basis } \\
\text { training courses and life long learning programs that are of international significance }\end{array}$ \\
\hline 19. & $\begin{array}{l}\text { Evaluate university partnership with vendors and technology companies in the development of } \\
\text { professional qualification programs that are offered on regular basis to the community }\end{array}$ \\
\hline 20. & $\begin{array}{l}\text { Evaluate involvement in twining activities that allow communities to integrate in the } \\
\text { development of better cultural understanding and access to knowledge resources }\end{array}$ \\
\hline
\end{tabular}

\section{Illustrative Example}

The German Jordanian University (GJU) is presented as an illustrative example of internationalization. It demonstrates the extent and success in mobility and cooperation in the internationalization context of an Arab country. GJU is modelled on the German universities of applied sciences, characterized by their focus on putting knowledge into practice and on promoting knowledge transfer. It is the largest DAAD educational project, with supporting funds provided since its inception. The achievements of GJU have been remarkable at the national and regional levels, by setting up a vibrant community of excellence.

GJU has established closer ties with many universities in Germany and others in Finland, Austria, and Sweden. Internationalization is adopted as a core policy with a German vice president appointed for international relations. An international office is established to coordinate student study and internship abroad as well as exchange of students, staff, and faculty. We illustrate the key internationalization aspects of GJU in regard to institutional partnership; curricula design; student study abroad; staff exchanges; research cooperation; and community engagement. These aspects are interlinked with each other and contribute largely to GJU with respect to international relevance in teaching, international value of research, and international engagement in community development. 


\subsection{Institutional Partnership}

GJU has grown both in size and stature over the past years. The growth of students every year has been $37 \%$ on average, reaching 3960 students in 2015. About 20\% of the students come from the neighbouring countries and Europe. GJU has a comprehensive German aspect in its teaching, operation, and functioning. All GJU students are required to pass 6 intensive German Language courses and are required to study for one full year in Germany. To facilitate teaching of German language and mobility of students, GJU employs German instructors and engages in several cooperation agreements with over 100 universities and 20 industries in Germany. GJU has strong multi-cultural communities open to dialogue for different ethnics, religious and social identities. Over 70 foreign students, mainly from Germany, study for a semester at GJU every year. Furthermore, several summer schools have been organized with over 60 students from Europe studying courses in technical and social fields together with students from Jordan. The study abroad and summer schools have largely contributed towards a true realization of GJU internationalization strategy and impacted better cultural awareness between the east and the west.

\subsection{Compatible Curricula Design}

GJU degree programs and curricula are designed and continuously updated by the relevant network members who represent professors from GJU and German partner universities. Curricula consist of courses with compatible credit hours, common reflection of learning outcomes, and comparable qualifications. The curricula have served as frameworks for dual and joint degree arrangements in a number of degree programs at the University. The curricula of the programs offered at GJU encourage personal development and facilitate students' exploring and pursuing entrepreneurial activities while in campus. The University in collaboration with the private sector has created varieties of Internships during the first year, to help students gain more real-world experience and developed optional short courses and workshops to help students improve leadership, project management, writing skills, and communication skills.

Much of the focus in teaching methods at GJU has been towards a student/ learner centric method, inherited through the ECTS (European Credit Transfer and Accumulation System). Although GJU implements the USA credit system as required by the ministry of higher education, still there has been some flexibility in recognizing ECTS credit transfer from the European partner universities. A system of equivalence has been adopted and reflected in a learning agreement with every student. Furthermore, the courses offered at GJU have adopted syllabi structure with learning outcomes defined as a result of curricula standardization.

In many cases, GJU and partner universities have signed bilateral framework of cooperation for student exchange. The framework provides a mechanism for student placement in host institutions. The mobility has been part of a credit transfer system between universities as reflected in student learning agreements. GJU through its experience has developed a transfer system between Jordanian credit system (USA inherited) and the European ECTS system.

\subsection{Study Abroad}

One full year at a German institution is part of the graduation requirements. The German Universities host GJU students for one academic semester and arrange 6 months industry internship in Germany. This exposes students to a wide range of scholars, researchers, and practitioners from foreign universities and industries. This year component is unique to GJU and a key differentiator. It gives GJU students a distinguished experience in terms of dynamism to select a focus area of study in a partner university and in practical training in a German industry.

The number of students who went for the compulsory one-year study abroad in Germany is growing at a rate of about $60 \%$, reaching to 570 students in 2015 . Student experiences in Germany vary and have been very promising in acquiring new knowledge and skills. Students enrol for about 20 ECTS in a German partner University, with instructions totally in German language. The results have shown that students performed well in the classes they take in Germany. More than $70 \%$ of the students pass all the courses. The internship experiences have been very rewarding to students. Students reported on gaining new knowledge, skills, qualifications, and new working habits that are important for the local job market. The internship feedback reports collected indicate a general consensus on GJU high level qualifications and disciplinary nature of students. Records of GJU Alumni indicated about $90 \%$ of the graduates have been employed in local, regional and international companies. The statistics show that $30 \%$ of GJU students work in Germany after they graduate, resulting in a brain drain issue in the broader context. Brain drain is usually regarded as an economic cost, resulting in the draining of skilled individuals if the graduates choose to stay in Germany in the longer term. It can also be argued that these students will help build better economies through transfer of knowledge back to their home country. 
In some arrangements, summer block courses are offered jointly to students from universities in Jordan and Europe. In average, 35 students from German universities study at GJU for a semerter. The students build teams to work on assignments and projects and established very good friendship as a sign of positive cultural understanding. Student personal feedbacks are mostly enthusiastic. Some of EU students even started to learn the Arabic language. Holding summer schools can be an effective strategy to motivate EU students to study on exchange to GJU. One essential factor for the enthusiasm of the German students was that they easily integrated with the GJU students. The strong orientation of this Jordanian university towards Germany and Europe created a climate in which the German students felt most welcome.

\subsection{Staff Exchange}

GJU through the relevant networks maintains a continuous flow of German faculty and staff for co-teaching and research collaboration. Through co-teaching assignments and student exchanges, capacity building and skill transfers have been inherent. As a matter of fact, much of the design of the courses has been based on integration of practical teaching assignments and theoretical lectures. This integration complemented by a compulsory 6 months internship in EU industry has a great impact of the quality of graduates of GJU.

During the co-teaching assignments, GJU and EU staff work together on developing course material, exams, grading, student projects, presentation, and more. For two summer terms, EU faculty members participated in co-teaching assignments for duration of one month. Several other flying faculty arrangements have been organized in different programs. Reports have shown over 50 co-teaching and flying faculty arrangements have been made at GJU. The number of German instructors, mainly teaching German language at GJU exceeds $30 \%$ of the total GJU faculty. This mix has contributed to developing closed cultural mix and integration.

Central aspects and activities of collaboration and exchanges contribute to various enhancements in the education system at GJU, including employability, mobility and cross-cultural understanding. The international component is a strong aspect in the whole concept of GJU. It is represented by extensive mutual exchange of students and faculty and the parallelization of curricula and teaching methods.

\subsection{Research}

Through cooperation with German institutions, GJU has been successful in building a quality research environment in areas related to water resources, renewable energy, system automation, and ICT. The statistics show that faculty raised more than one million US Dollar (USD) as external grants from funding agencies and industry and about half a million USD as internal/ seed grants. In 2011, a total of 3 TEMPUS grants were awarded by the EC to Jordan for institutional and program development. In addition, GJU faculty has been involved in a number of projects funded by through FP 7 , DFG and DAAD.

GJU has made a tremendous effort to motivate its faculty to carry out research and innovation in areas of relevance to the region and solicit internal and external funding. GJU has provided constantly seed funding grants to faculty to initiate research ideas and project concepts that can be external funded in the long term.

\subsection{Evaluation Merits}

To demonstrate the GJU example, we present metrics of different elements in the internationalization framework. As it is exemplified in tables 5, 6, and 7, the metrics demonstrated are: partnership and mobility on variety of dimensions. Performance metrics on returns, outcomes, and employment are also demonstrated. The metrics give measures on the level of effort expended in developing a successful bi-national higher educational institution that can be utilized for improving internationalization dimension. Within this setup, internationalization is embedded at the policy level within a solid cooperation framework. The metrics related to mobility and knowledge transfer indicate a large number of students involved in study abroad, $30 \%$ of staff are international, large number of exchanges and joint projects. 
Table 5. Metrics of internationalization framework - partnership

\begin{tabular}{ll}
\hline Metric & Value description \\
\hline Policy & 1-year study abroad is mandatory for all students \\
Cooperation agreements & $\sim 110$ Universities mainly in Germany \\
Cultural integration & 6 German language courses +1 intercultural communication course in the \\
& study plan \\
Structure & GJU project office in Germany \\
& International office at GJU \\
Program development & Curricula co-designed with German partners \\
Joint projects & $\sim 10$ joint projects with German partners supported by Tempus, DFG, and \\
& FP7
\end{tabular}

Table 6. Metrics of internationalization framework - mobility

\begin{tabular}{ll}
\hline Metric & Value description \\
\hline $\begin{array}{l}\text { Semester abroad in } \\
\text { German University }\end{array}$ & $\sim 550$ students enroll in about 90 German universities every year \\
Internship in German & $\sim 550$ students spend 5-6 months internship in German industry \\
industry & \\
Research visits & $\sim 15$ research visits in 2012/2013 \\
Foreign Employment & $\sim 10 \%$ of graduates get jobs in German industry \\
Staff exchange & $\sim 50$ German instructors and faculty work for GJU (30\%). \\
& $\sim 15$ flying faculty each year in both directions \\
& 5 administrative staff \\
\hline re Metrics and their perspective values \\
\hline Metric & Value description \\
\hline $\begin{array}{l}\text { Specific } \\
\text { academic excellence }\end{array}$ & Improve student skills and competencies \\
& Develop mutual links with German universities and industry \\
Job market mismatch & New academic programs are developed \\
Improved & Increased awareness of latest sciences and technologies. \\
& Curricula designed to meet job market requirements \\
& Focus on practical aspects \\
\hline
\end{tabular}

\section{Conclusion}

This paper presented an internationalization framework of higher education in the Arab regional context. Analysis of trends and conceptualization of the status of Arab higher education system are presented. Internationalization is seen as a key to development and has been expanding very rapidly. Its realization can be made through variety of dimensions including mobility for teaching and learning, exchange programs for research, and partnerships with foreign universities for institutional linkage. A framework is presented as a benchmark for internationalization, with its measurable elements focusing on different perspectives related to teaching, research and community. These elements can be used to guide efforts towards a strengthened position of higher education in the international dimension. The framework is used to match the extent and success of its elements at the GJU example of a bi-national university with strong ties with German universities. The key findings of this example are: (1) Mobility of students and staff is a key to internationalization and largely contributes to developing skills for the job market; (2) Brain drain is considered an issue but could support better links for knowledge transfer and cultural integration; (3) Cooperation, joint curricula development, and staff exchanges are distinctive elements of success. The metrics given in this paper demonstrate the 
level of success in the quality of teaching and learning as well as research, which have resulted through cooperation, exchanges, and practical experiences. The GJU example can be generalized for a true realization of new cooperative models of higher education systems in the context of internationalization. It represents a case study of an approach to internationalization.

\section{Acknowledgements}

The authors would like to acknowledge the support of the League of Arab States in developing the initial concept paper with insights from HE Faeqa Al Saleh. Special thanks are to Professor Jane Knight for her insightful reviews, Professor Jomana Amara for several inputs and linguistic reviews, and Professor Anne Lequy for her review and input on the German dimension.

\section{References}

Akkari, A. (2004). Education in the Middle East and North Africa: The Current Situation and Future Challenges. International Education Journal, 5(2), 144-153.

Arab League Educational, Cultural and Scientific Organization - ALECSO Report (2010). Arab Strategy for Scientific Research, Technology, and Innovation, URL: http://www.alecso.org.tn

Altbach, P., \& Knight J. (2007). The Internationalization of Higher Education: Motivations and Realities. Journal of Studies in International Education, 1(3/4), 290-305. https://doi.org/10.1177/1028315307303542

Arabkheradmand, A., Enayat, S., Zand-Moghadam, A., Bahrami, H., Derakhshesh, A., \& Golkhandan, A. (2015). An Introduction to the Internationalization of Higher Education: Essential Topics. United States: University Press of America Inc.

Ayoubi M., \& Massoud K. (2007). The strategy of internationalization in Universities: A quantitative evaluation of the intent and implementation in UK universities. International Journal of Educational Management, 21(4), 329-349. https://doi.org/10.1108/09513540710749546

Badran, A. (2005). The Arab States, United Nations Educational, Scientific and Cultural Organization - UNESCO Science Report. http://www.unesco.org/new/fileadmin/MULTIMEDIA/HQ/SC/pdf/sc_usr05_arab_en.pdf

Bartell, M. (2003). Internationalization of universities: A university culture-based framework. Higher Education, 45(1), 43-70. https://doi.org/10.1023/A:1021225514599

Brandenburg, U. \& Federkeil, G. (2007). How to measure internationality and internationalization of higher education institutions! Indicators and key figures. Center for Higher Education Development, Working paper No. 92, URL: http://www.che.de/

Coelen, R. (2009). Ranking and the measurement of success in internationalization: are they related?. Measuring success in the internationalization of higher education, de Wit, H. (eds) (Vol. EAIE occasional paper 22), 39-47.

de Wit, H. (2011). Trends, Issues and Challenges in Internationalization of Higher Education. Centre for Applied Research on Economics and Management, Hogeschool van Amsterdam.

Jaramillo, A., Ruby A., Henard, F., Zaafrane H. (2011). Internationalization of Higher Education in MENA: Policy issues associated with skills formation and mobility, Worldbank Report No. 63762-MNA

Knight, J. (2003). Internationalization of Higher Education Practices and Priorities. International Association of Universities Survey Report.

Knight, J. (2004). Internationalization remodelled: Definition, approaches, and rationales. Journal of Studies in International Education, 8(1), 5-31. https://doi.org/10.1177/1028315303260832

Knight, J. (2006). Internationalization of higher education: New directions, new challenges. International Association of Universities Global Survey Report.

Lamine, B. (2010). Regional Report: A Decade of Higher Education in the Arab States (1998 - 2009): Achievements and Challenges, Proceedings of the Arab Regional Conference on Higher Education.

Marjorie, L. (2000). Higher Education and the Global Marketplace: A Practical Guide to Sustaining Quality. On the Horizon, 8(5), 7-10. https://doi.org/10.1108/10748120010803555

Marginson, S. (2006). Dynamics of national and global competition in higher education. Higher Education, 52, 1-39. https://doi.org/10.1007/s10734-004-7649-x 
Maringe, F., Foskett, N. (2010). Globalization and Internationalization in Higher Education: Theoretical, Strategic and Management Perspectives. London, UK: Bloomsbury publishing Plc.

Mazawi, A. (2006). Contrasting Perspectives on Higher Education Governance in the Arab States, Higher Education: Handbook of Theory and Research, 20,133-189. https://doi.org/10.1007/1-4020-3279-X_3

Middle East Institute - MEI Report (2010). Higher Education and the Middle East: Serving the Knowledge-based Economy. http://www.mei.edu

Qiang, Z. (2003). Internationalization of Higher Education: Towards a Conceptual Framework. Policy Futures in Education, 1(2), 248-270. https://doi.org/10.2304/pfie.2003.1.2.5

Rena, R. (2010). Emerging Trends of Higher Education in Developing Countries. Analele Stiintifice ale Universitatii, $47(2), 301-316$.

Rizvi, F. \& Lingard, B. (2009). Globalizing Education Policy. New York, NY: Routledge.

Siaya, L. \& Hayward, F. (2003). Final report: Mapping internationalization on U.S. campuses. Washington, DC: American Council on Education.

Schwalje, W. (2010). Presentation: Arab World Higher Education Situation Analysis and Options. URL: http:// www.slideshare.net/

United Nations Development Programme - UNDP Report (2009). Arab Human Development Report, Challenges to Human Security in the Arab Countries. http://www.arabstates.undp.org

United Nations Educational, Scientific and Cultural Organization - UNESCO Report. (2009). Towards an Arab Higher Education Space: International Challenges and Societal Responsibilities. https://unesdoc.unesco.org/ark:/48223/pf0000189272

Varghese, N. (2008), Globalization of higher education and cross-border student mobility. Publication of UNECO. https://unesdoc.unesco.org/ark:/48223/pf0000157989

Van der Wende, M. (2007). Internationalization of higher education in the OECD countries: Challenges and opportunities for the coming decade. Journal of Studies in International Education, 11(3/4), 274-289. https://doi.org/10.1177/1028315307303543 